\title{
Tadeusz Dziedzic
}

e-mail: tadeuszdziedzic04@wp.pl

ORCID: 0000-0002-3355-8225

DOI: $10.15290 / \mathrm{mhi} .2020 .19 .02 .16$

\section{David Lloyd George a sprawa polska na konferencji wersalskiej}

\begin{abstract}
Abstrakt
Traktat wersalski został podpisany po wielomiesięcznych obradach konferencji pokojowej zwołanej do Paryża, po zakończeniu I wojny światowej w dniu 28 czerwca 1919 r. w Paryżu, przez Niemcy i państwa Ententy. Wszedł w życie z dniem 10 stycznia 1920 r., tj. z dniem jego ratyfikacji. W konferencji pokojowej w Paryżu uczestniczyły delegacje 27 zwycięskich państw. Traktat gruntownie zmienił mapę Europy i panujący ład polityczny. Na mapie znalazło się wiele małych państw, w tym Rzeczypospolita Polska na nowo zaistniała na mapach Europy, choć w mniejszym niż przed rozbiorami posiadaniu terytorialnym. Delegacja polska, w której znaleźli się m.in: Ignacy Jan Paderewski czy Roman Dmowski zabiegała ze wszystkich sił, by przywrócić Polakom ich ziemie, ziemie, które na skutek rozbiorów znalazły się pod władaniem trzech mocarstw: Prus, Austrii i Rosji. Jednakże konferencja pokojowa w Paryżu ukazała wiele niechęci ze strony Wielkiej Piątki, decydującej o losach powojennej Europy w stosunku do Polski. Oczekiwania Polaków, że ich sprawa zostanie poparta przez zaprzyjaźnionych Brytyjczyków, czy Amerykanów, czy wreszcie Francuzów okazały się złudne. Zwłaszcza Francuzi, którzy wydawali się nader do Polski przychylnie ustosunkowani, na konferencji pokojowej zupełnie podporządkowali się woli Brytyjczyków, którym wręcz zależało, by przeszkodzić Polakom w ich dążeniu do przywrócenia przedrozbiorowych granic. Głównym wyrazicielem nieprzychylności Brytyjczyków do sprawy polskiej okazał się być ówczesny premier Wielkiej Brytanii - David Lloyd George, który był tak nieprzejednany w swym stanowisku, że nie przemawiały do niego żadne argumenty, na które powoływała się delegacja polska.
\end{abstract}




\section{Abstract \\ David Lloyd George and the Polish matter during the Versailles Conference}

The Treaty of Versailles was signed after several months of deliberations at a peace conference convened to Paris after the end of World War I on 28 June 1919 in Paris by Germany and the Entente countries. It entered into force on 10 January 1920, i.e., on the day of its ratification. Delegations of 27 winning countries participated in the peace conference in Paris. The treaty completely changed the map of Europe and the prevailing political order. Many small countries found their place on the map, including the Republic of Poland re-emerging on the maps of Europe, although in smaller territorial ownership than before the Partition of Poland. The Polish delegation, including among others: Ignacy Jan Paderewski and Roman Dmowski, tried their best to restore the Poles to their lands. Lands which, as a result of the Partition, came under the rule of three powers, namely: Prussia, Austria, and Russia. However, the peace conference in Paris showed much reluctance on the part of the Big Five, which decided about the fate of post-war Europe towards Poland. Expectations of the Poles that their case would be supported by friendly British, American, or French politicians turned out to be deceptive. Especially the French, who seemed very favourable to Poland, at the peace conference completely obeyed the will of the British, who even intended to prevent the Poles in their quest to restore the pre-partition Polish borders. The British Prime Minister David Lloyd George, who turned out to expose his unfavourable attitude towards the Polish cause, was so uncompromising in his position that no arguments invoked by the Polish delegation appealed to him.

Słowa kluczowe: David Lloyd George, Traktat wersalski, I wojna światowa, konferencja pokojowa w Paryżu, Polska

Key words: David Lloyd George, Treaty of Versailles, World War I, Paris Peace Conference, Poland

W niniejszym tekscie podjęto próbę przedstawienia ewolucji poglądów brytyjskiego premiera Davida Lloyd George'a w sprawie międzynarodowej pozycji Polski w czasie I wojny światowej oraz w sprawie polskiej granicy z Niemcami. Najważniejsze decyzje graniczne zapadły na konferencji wersalskiej, a jednym z ich głównych autorów był brytyjski premier. Czytelnika dziwić może kolejny głos w tak już bardzo obfitej literaturze na ten temat. Moje zainteresowanie tematem jest poboczne i wynika $z$ badań nad ewolucją ustrojową pozycji premiera brytyjskiego. Premierostwo D. Lloyd George'a (od 1916 r.) oraz stworzony przezeń Gabinet Wojenny (War Cabinet) były bowiem 
ważnymi wydarzeniami $\mathrm{w}$ tej ewolucji ${ }^{1}$. Ponadto ukazanie się ważnej pracy A. Nowaka ${ }^{2}$ również uzasadnia tę krótką wypowiedź. Pozwolę sobie także wyrazić przekonanie, że poruszany przeze mnie temat łączy się z prawno-polityczną historią stosunków polsko-niemieckich, będącą tematem przewodnim niniejszego numeru czasopisma.

Traktat wersalski został podpisany przez Niemcy i państwa Ententy 28 czerwca 1919 r., po wielomiesięcznych obradach konferencji pokojowej zwołanej do Paryża, po zakończeniu I wojny światowej. Ratyfikowany został przez polski Sejm Ustawodawczy 31 lipca 1919 r. ${ }^{3}$ Wszedł w życie 10 stycznia 1920 r. Konferencja odbywała się od 18 stycznia 1919 r. do 21 stycznia 1920 r. ${ }^{4}$ Wybór Paryża na miejsce konferencji nie był oczywisty i nie nastąpił od razu. Rozpatrywano kandydaturę kilku miast, m.in. Lozanny, a potem Genewy, leżącej w Szwajcarii, ale ostatecznie decydujący głos w sprawie wyboru miejsca konferencji pokojowej w Paryżu mieli Francuzi, przy całkowitym ustępstwie w tej materii Brytyjczyków, którzy kwestię miejsca uznali za drugorzędną i przystali na propozycję ${ }^{5}$. Najważniejszą częścią konferencji paryskiej była konferencja wersalska, dotycząca warunków zawarcia pokoju z Niemcami.

Polska ostatecznie przez Sejm Ustawodawczy RP, 31 lipca 1919 r. ratyfikowała traktat pokojowy $\mathrm{z}$ Niemcami ${ }^{6}$ oraz tzw. mały traktat wersalski, mimo iż nie wszystkie postulaty Polaków uwzględniały traktaty ${ }^{7}$.

Regulacje traktatu nakładały na Niemcy wiele niekorzystnych $\mathrm{z}$ ich punktu widzenia zobowiązań. Należały do nich m.in. zapłata reparacji wojennych, których wysokość później wskazano na kwotę łącznie 132 mld marek w złocie. Bardzo dotkliwe były cesje terytorialne przewidziane przez traktat. Niemcy zobowiązane zostały do rezygnacji ze wszystkich kolonii, jakie były pod ich władaniem. Alzacja i Lotaryngia, miały zostać zwrócone Francji. Warunki szczegółowo zostały omówione w dziale V traktatu. Cesja Alzacji i Lotaryngii uregulowana została w art. od 51 do 79 oraz w aneksie do traktatu. Ponadto,

1 Zob. szerzej na ten temat: K. Prokop, Dyktatura brytyjskiego gabinetu w czasie I wojny światowej, [w:] Prawo, parlament i egzekutywa we współczesnych systemach rządów: księga poświęcona pamięci Profesora Jerzego Stembrowicza, red. S. Bożyk, Białystok 2009, s. 316-329.

2 A. Nowak, Pierwsza zdrada Zachodu. Zapomniany appeasement, Kraków 2016. Zob. także artykuł recenzyjny: L. Kuk, Między wielkościq a małością. Polska wobec koncertowej kakofonii mocarstw na przełomie swych dziejów (1914-1945), „Kwartalnik Historyczny” 2017, z. 1, s. 123-148.

3 Traktat pokoju między mocarstwami sprzymierzonemi i skojarzonemi i Niemcami, podpisany w Wersalu 28 czerwca 1919 r. (Dz.U. $1920 \mathrm{nr}$ 35, poz. 200).

4 H. Batowski, Między dwoma wojnami 1919-1939. Zarys historii dyplomatycznej, Kraków 2001, s. 28-35.

5 E. J. Dillon, Konferencja pokojowa w Paryżu 1919, Warszawa 1921, s. 1.

6 Ustawa z dnia 31 lipca 1919 r. o ratyfikacji traktatu pokoju (Dz.U. $1920 \mathrm{nr} 35$, poz. 199).

7 Traktat między głównemi Mocarstwami sprzymierzonemi i stowarzyszonemi a Polską, podpisany w Wersalu 28 czerwca 1919 r. (Dz.U. 1920 nr 110, poz. 728). 
Niemcy zobowiązane zostały do oddania Zagłębia Saary, na okres 15 lat, pod protektorat Ligii Narodów, co zostało uregulowane w części III, dziale IV, w art. 45-50 traktatu. W późniejszym czasie o przynależności tego terytorium zdecydować miał plebiscyt, przeprowadzony wśród mieszkańców. Ponadto traktat przewidywał cesję okręgu Eupen i Malmedy na rzecz Belgii.

Ustalono również, że Niemcy nie mogą posiadać ciężkiej broni artyleryjskiej, broni pancernej, okrętów wojennych, oraz lotnictwa bojowego. Liczebność armii ograniczono do 100 tysięcy żołnierzy, warunki powyższe szczegółowo uregulowano w części V Traktatu, pt: Przepisy dotyczące wojska, marynarki i lotnictwa, w art. 159-202.

Jednak największe straty terytorialne poniosły Niemcy na rzecz Polski (art. 87-98 traktatu). W zakresie granic z Polską Niemcy zostały zobowiązane do przekazania na rzecz Polski części swoich obszarów wschodnich: Poznańskiego i Pomorza. Przewidziano również plebiscyt na Górnym Śląsku oraz na Warmii, Mazurach i Powiślu, które miały zdecydować o przynależności państwowej tych ziem. Traktat przewidywał ponadto utworzenie Wolnego Miasta Gdańska (art. 100-108), co oznaczało odłączenie tego miasta od Rzeszy.

W konferencji pokojowej w Paryżu uczestniczyły delegacje 27 zwycięskich państw.

Państwa, które zostały pokonane w I wojnie światowej, tj. Niemcy, Austro-Węgry, Imperium Osmańskie, Bułgaria; nie były dopuszczone do rozmów i negocjacji podczas trwania konferencji. Zostały im przedstawione gotowe teksty traktatów do podpisania. W tym kontekście słowo dyktat, używane stale przez Niemców, wydaje się być bardziej właściwe.

Traktat wersalski gruntownie zmienił mapę Europy i panujący ład polityczny. Na mapie znalazło się wiele nowych państw, w tym Rzeczpospolita Polska, choć w mniejszym niż przed rozbiorami rozmiarze terytorialnym.

Delegacja polska, w której znaleźli się z pełnymi umocowaniami przez $\mathrm{Na}$ czelnika Państwa Józefa Piłsudskiego - prezydent ministrów Ignacy Jan Paderewski i prezes Komitetu Narodowego Polskiego Roman Dmowski, zabiegała co do zasady, by przywrócić Polakom dawne terytoria I Rzeczypospolitej, czyli Polski w granicach sprzed rozbiorów.

Zarówno Roman Dmowski jak i Ignacy Jan Paderewski włożyli wiele wysiłku w odbudowę międzynarodowej pozycji najpierw narodu, a następnie państwa polskiego już od początku I wojny światowej. Ten ostatni w styczniu $1915 \mathrm{r}$. roku opracował list do prezydenta Francji - Raymonda Poincare w sprawie stosunków polsko-francuskich, oraz możliwości poparcia Francji dla sprawy polskiej. Konsekwentnie wiązał w nim sprawę polską z poparciem Francji ${ }^{8}$. Wraz z Henrykiem Sienkiewiczem zabiegał o jak najszersze poparcie dla działalności

8 M. Drozdowski, Ignacy Jan Paderewski, Warszawa 1986, s. 73-75. 
Komitetu Vevey, który powstał 9 stycznia 1915 r. z inicjatywy przebywających na emigracji intelektualistów i polityków w Lozannie. Następnie Komitet został przeniesiony do Vevey 27 stycznia 1915 r. ${ }^{9} \mathrm{Na}$ czele Komitetu stanęli Ignacy Paderewski i Henryk Sienkiewicz. Nawiązując do przyjaźni polsko-francuskiej, liczył, że Francja zainteresuje się losem doświadczonych przez wojnę Polaków. Ignacy Paderewski starał się do akcji „Komitetu Vevey”, uzyskać poparcie wszystkich wpływowych środowisk paryskich, a Henryk Sienkiewicz zredagował apel do Polonii oraz „Do ludów ucywilizowanych” o pomoc materialną dla ludności polskiej. Komitet, dzięki działalności I. Paderewskiego i H. Sienkiewicza, do września 1916 r. zebrał około 4 milionów dolarów. Komitet Vevey działał za pośrednictwem rozsianych po całym świecie lokalnych komitetów - w sumie było ich $174^{10}$.

Podobna akcja miała miejsce na terytorium Wielkiej Brytanii. Początek aktywności polskiej na Wyspach wiązać należy z osobą Józefa Konrada Korzeniowskiego, który od początku wojny prowadził ożywioną działalność publicystyczną propagującą sprawę polską ${ }^{11}$. Jego esej o zbrodni rozbiorów (the crime of partition) wywarł wieki wpływ wśród establishmentu brytyjskiego. Z kolei pod koniec marca 1915 r. I. J. Paderewski przyjechał do Londynu, gdzie przystąpił do założenia Polish Victims' Relief Fund. Fundacja zrzeszała najwybitniejszych członków angielskiego towarzystwa i sfer rządowych, m.in. Księstwo Norfolk, Księstwo Somerset, księżna Bedford, Winston Churchill, markiz Ripon wraz z małżonką. Członkiem Fundacji został także David Lloyd George, co świadczyłoby o zainteresowaniu tego polityka problematyką polską. Czym innym jest jednak uczestnictwo w charytatywnej akcji pomocy ofiarom wojny, a czym innym uprawianie polityki. Na tym gruncie obowiązywała bowiem stara angielska zasada, iż Wielka Brytania nie ma stałych przyjaciół czy wrogów, ma tylko stałe interesy ${ }^{12}$.

Podpisy Ignacego Paderewskiego oraz Romana Dmowskiego znalazły się pod umową pokojową, tj. Traktatem pokoju pomiędzy państwami Sprzymierzonemi i Skojarzonemi i Niemcami podpisanym 28 czerwca 1919 r. w Wersalu. Obaj zabiegali, by ziemie, które na skutek rozbiorów Polski znalazły się pod władaniem trzech mocarstw, znowu tworzyły jednolitą i niepodległą Polskę. Uzasadniając swoje stanowisko w liście do przewodniczącego Komisji Terytorialnej, która rozpatrywała polskie wnioski, Roman Dmowski pisał:

9 Ibidem, s. 72-76.

10 D. Płygawko, Sienkiewicz w Szwajcarii, Poznań 1986, s. 54-57.

11 K. Samsel, Publicystyka niepodległościowa Josepha Conrada i jej postromantyczne uwikłania, „Perspektywy Kultury" 2019, t. 24, nr 1, s. 39-50.

12 J. Złotkiewicz-Kłębukowska, Od Balfoura do Curzona - polityka Wielkiej Brytanii wobec odradzającej się Polski 1918-1920, „Annales Universitatis Mariae Curie-Skłodowska. Sectio F - Historia” 2009, t. LXIV, s. 45. 
„że za punkt wyjścia do polskich żądań przyjmujemy rok 1772, czyli datę pierwszego rozbioru Polski"'13.

Jednakże przebieg obrad konferencji pokojowej w Paryżu ukazał wiele niechęci ze strony Wielkiej Piątki, decydującej o losach powojennej Europy, także w stosunku do Polski. Państwa Wielkiej Piątki to: Stany Zjednoczne, Wielka Brytania, Francja, Japonia i Włochy - to one spośród 27 państw sprzymierzonych, tworzących zwycięską koalicję, posiadały rzeczywisty wpływ na przebieg i efekt pokojowej konferencji, zwołanej do Paryża. Pierwotnie ośrodek decyzyjny tworzyli szefowie państw Wielkiej Piątki, wraz z ministrami spraw zagranicznych, łącznie 10 osób. Następnie jednak zrezygnowano z udziału ministrów w ścisłych obradach, tym samym pozostała tylko piątka decydentów. Oczekiwania Polaków, że ich sprawa zostanie jednoznacznie poparta przez zaprzyjaźnionych Brytyjczyków i Amerykanów, okazały się złudne. Zwłaszcza Amerykanie, którzy wydawali się nader do Polski przychylnie ustosunkowani, na konferencji pokojowej zupełnie podporządkowali się woli Brytyjczyków, którym wręcz zależało na tym, by przeszkodzić Polakom w ich dążeniu do przywrócenia przedrozbiorowych granic Polski. Ważną w tym stanowisku rolę odegrała Wilsonowska zasada samostanowienia narodów ${ }^{14}$ (akceptację dla której D. Lloyd George wielokrotnie podkreślał) i związane z nią próby rozgraniczenia państw na podstawie etnicznego kryterium większościowego. To zaś w wielu przypadkach nie dawało się pogodzić z postulatem przywrócenia granic przedrozbiorowych.

Natomiast pozytywny stosunek do sprawy polskiej reprezentowała delegacja francuska. Jednak jej stanowisko należało rozpatrywać na tle przede wszystkim stanowiska brytyjskiego, którego istota objawiała się w niedopuszczeniu do budowy hegemonii politycznej Francji w Europie. Rzutowało to na stosunek Brytyjczyków do problemów polskich na konferencji.

Głównym wyrazicielem stanowiska Brytyjczyków był premier rządu JKM David Lloyd George, który zdominował delegację brytyjską do tego stopnia, iż pozycja brytyjskiego ministra spraw zagranicznych (szefa Foreign Office FO) była całkowicie drugorzędna ${ }^{15}$. W wydanych przez siebie wspomnieniach $\mathrm{z}$ konferencji paryskiej napisał, że w trakcie trwania konferencji Polacy sprawiali najwięcej kłopotów, gdyż, jak podkreślił David Lloyd George, Polacy ubzdurali sobie, że ich ojczyzna znów stanie się niekwestionowaną władczynią Europy Środkowej ${ }^{16}$. Jednak w świetle wspomnień nie można bynajmniej odnieść wrażenia, jakoby sprawa granic polskich zajmowała dużo jego uwagi. Nie sposób

13 A. Czubiński, Historia Polski XX wieku, Poznań 2007, s. 85-88.

14 Szerzej na ten temat: P. Fiedorczyk, A. Lityński, A. Stawarska-Rippel, Wojny XX wieku i ich skutki dla ustrojów państwowych i prawa, „Czasopismo Prawno-Historyczne” 2019, t. LXXI, z. 1, s. 65-67.

15 J. Złotkiewicz-Kłębukowska, op. cit., s. 45-46.

16 D. Lloyd George, Prawda o traktacie wersalskim, t. I-II, Warszawa 1938, s. 276-277. 
pominąć faktu, iż David Lloyd George miał słabe, żeby nie powiedzieć żadne, rozeznanie geograficzne oraz etniczne w Europie Środkowo-Wschodniej ${ }^{17}$. W swoich wspomnieniach pisał: „Nikt nie sprawiał większego kłopotu niż Polacy. Upojona młodym winem wolność, dostarczonym przez Aliantów, Polska wyobrażała sobie, że jest znów panią losów Europy Środkowej”" ${ }^{\prime 1}$. Niestety, to także dodatkowo obarczało, już i tak złe z polskiego punktu widzenia, decyzje w sprawie polskiej, podejmowane przez rząd brytyjski.

Wyznacznikiem w polityce międzynarodowej, dla Davida Lloyd George'a był przede wszystkim, co zrozumiałe, interes Wielkiej Brytanii, a ta - patrząc na swoje interesy w Europie - widziała przede wszystkim problem Niemiec i Rosji. W wyniku zwycięskiej wojny Wielka Brytania uznawała, że są to kraje, z którymi należy ostrożnie się obejść, jednocześnie nie dopuszczając Francji do zbyt wielkich wpływów na kontynencie.

Tymczasem Wielka Brytania, przystępując do wojny w 1914 r., w żaden sposób nie określiła jednoznacznie swoich celów wojennych w sprawie polskiej, nie licząc mało znaczącego memoriału prof. Bernarda Pares’a z 8 października 1914 r., zatytułowanego The Polish Question. Profesor B. Pares pisał, że podjęcie sprawy polskiej w zakresie roszczeń do ziem znajdujących się pod zaborem pruskim będzie uzależnione od sukcesów armii rosyjskiej. Takie założenie miało z pewnością swoje oparcie w sojuszu Anglii, Francji i Rosji, a doprowadziło do takich kuriozalnych sytuacji, że w 1915 r. francuska cenzura wydała zakaz przedruku w gazecie polskiej w Paryżu artykułów z prasy rosyjskiej, w których zawarta była krytyka stanowiska rządu rosyjskiego wobec sprawy polskiej ${ }^{19}$. $\mathrm{Na}$ początku wojny problem polski był więc w zasadzie problemem rosyjskiego alianta.

Sytuacja taka trwała przez kolejne dwa lata, gdyż dodatkowo ówczesny szef Foreign Office, Edward Grey, wyznawał zasadę, że w trakcie trwania działań wojennych dyplomacja ma niewiele do powiedzenia ${ }^{20}$. Jednakże już w $1916 \mathrm{r}$. powstały trzy brytyjskie memoriały w sprawie warunków do negocjacji przyszłego pokoju w Europie. W imieniu Foreign Office przygotowany przez urzędników ministra tj. Ralpha Pageta i Williama Tyrela, a w imieniu Admiralicji i Imperialnego Sztabu Generalnego przez ich kierowników Arthura Jamesa Balfoura i Williama Robertsona. W powyższych memoriałach pojawił się również problem przyszłych granic Polski, związanych z Rosją ${ }^{21}$. Najwyraźniejszy

17 E. J. Dillon, op. cit., s. 126-131.

18 D. Lloyd George, op. cit., s. 277-278.

19 A.M. Cienciała, Polityka brytyjska wobec odrodzenia Polski, 1914-1918, „Zeszyty Historyczne” 1969, nr 16, s. 79.

20 P. Karaszewski, Kryzys autorytetu Foreign Office w latach 1914-1922, „Dzieje Najnowsze” 1977, z. 2, s. 82.

21 J. Złotkiewicz-Kłębukowska, op. cit., s. 2. 
sygnał w sprawie polskiej znalazł się w memoriale z 4 października 1916 r., The Peace Settlement in Europe. Arthur James Balfour ${ }^{22}$, kreśląc zarys umowy pokojowej dla powojennej Europy, kierował się - głównie brytyjskim interesem narodowym, który to $\mathrm{w}$ niczym nie zaspokajał polskich dążeń niepodległościowych, wręcz był rozbieżny z polskim stanowiskiem. Wielka Brytania nie widziała w Europie miejsca dla wolnej Polski, jedynie zaś Polski, która miałaby pozostawać częścią Rosji, posiadając autonomię i stanowić „arenę nieustannych intryg" ${ }^{23}$. Uważał, że z punktu widzenia interesów brytyjskich, najlepiej, by Polska składała się z Zachodniej Galicji, Kongresówki, i w pewnym stopniu z ziem zaboru pruskiego. Nawet po ogłoszeniu przez prezydenta USA Thomasa W. Wilsona w dniu 22 stycznia 1917 r. postulatu stworzenia wolnej Polski, Wielka Brytania ustami ministra spraw zagranicznych A. Balfoura i premiera D. Lloyd George'a, sprzeciwiała się oddaniu Polsce dostępu do morza, a także Gdańska, gdyż jak twierdzono, odcięłoby to Prusy Wschodnie od Niemiec. Przeciwna była również oddaniu Polsce całego Poznańskiego, gdyż tutaj widziała niebezpieczeństwo, wynikające ze zbyt niewielkiej odległości Berlina od granicy polskiej (de facto rosyjskiej) ${ }^{24}$. Stanowisko Wielkiej Brytanii już jesienią 1917 r. uległo jednak zmianie na korzyść Polaków. Kwestia ogłoszenia Polski niepodległej, jako celu wojennego Brytyjczyków, znalazła się w oficjalnym stanowisku, bezpośrednio po tym jak Polski Komitet Narodowy upomniał się o oficjalną odezwę aliantów w tej kwestii. Kluczem dla zmiany stanowiska Wielkiej Brytanii była oczywiście rewolucja w Rosji i upadek caratu.

Polski Komitet Narodowy uznany został za oficjalną agencję polską na zachodzie Europy. Pierwsze wyraźne uznanie Polskiego Komitetu Narodowego, a także armii polskiej utworzonej we Francji, wyraziła oczywiście Francja, która upatrywała w Polsce, wobec upadku Rosji, swego rodzaju wschodnią barierę przeciwko Niemcom.

Upragniona i wyczekiwana przez Polaków odezwa aliancka, głównie amerykańsko-brytyjska, miała miejsce w styczniu 1918 r. Premier Wielkiej Brytanii, David Lloyd George w imieniu rządu JKM wyraził poparcie dla niepodległej Polski, złożonej z ziem zamieszkanych przez ludność bezspornie polską ${ }^{25}$. Natomiast prezydent USA T. W. Wilson, 8 stycznia 1918 r. w orędziu do Kongresu ogłosił swój czternastopunktowy program pokojowy. W punkcie 13 stwierdzał, że celem wojny jest powstanie niepodległej Polski obejmującej wszystkie ziemie etnicznie polskie, z wolnym dostępem do morza ${ }^{26}$. Dekla-

22 Arthur James Balfour - brytyjski polityk, piastował m.in. stanowisko premiera, ministra spraw zagranicznych, ur. 25.07.1848 r. w Whittingehame. Zmarł 19.03.1930 r. w Fisher’s Hill k. Woking.

23 W. Sukiennicki, Balfour a Polska, „Zeszyty Historyczne” 1970, nr 17, s. 41.

24 A. M. Cienciała, op. cit., s. 79-94.

25 J. Złotkiewicz-Kłębukowska, op. cit., s. 42.

26 S. Sierpowski, Studia do historii powszechnej okresu międzywojennego, t. 1, Poznań 1989, s. 27-32. 
racje te nie stanowiły żadnego konkretnego stanowiska w sprawie zachodnich granic Polski.

W trakcie trwania konferencji paryskiej w dniu 12 marca 1919 r., Komisja J. Cambona przedstawiła Wielkiej Piątce, stanowiącej Radę Najwyższą konferencji, raport o granicy polsko-niemieckiej, w dużej mierze uwzgledniający wcześniejsze postulaty I. Paderewskiego i R. Dmowskiego. W raporcie wskazano terytoria, które winny zostać przyznane Polsce po zakończeniu działań wojennych, a były to: Górny Śląsk, Wielkopolska, Pomorze Gdańskie, Gdańsk, cztery powiaty leżące na prawym brzegu Wisły, a także niewielka część Dolnego Śląska. W zaleceniach komisji znalazła się również propozycja przeprowadzenia plebiscytu na Mazurach.

Propozycje komisji spotkały się niemal natychmiast z dezaprobatą Davida Lloyd George'a, który zdecydowanie sprzeciwiał się tworzeniu silnej Polski, kosztem osłabienia Niemiec, w których widział realną przeciwwagę dla Francji i za wszelką cenę nie chciał dopuścić do jej dominacji w Europie.

Sprawa wolnego dostępu Polski do morza została podniesiona w już czerwcu 1918 r., również przez Wielką Brytanię, Francję i Włochy. Włosi, przez barona S. Sonnino, ministra spraw zagranicznych, długo sprzeciwiali się przyznaniu Polsce wolnego dostępu do morza, ale brytyjski minister A. Balfour przekonał go mówiąc, że zdanie o wolnym dostępie nie oznacza oddania Polakom Pomorza i Gdańska ${ }^{27}$.

Kolejny memoriał, spisany przez A. Balfoura w dniu 18 października 1918 r., dotyczył granicy polsko-niemieckiej. Potwierdzając w nim swoje poprzednie stanowisko, w którym nie widział możliwości oddania Polakom Gdańska i Pomorza - proponował jedynie wolny port w Gdańsku. Był zwolennikiem, by Niemcy zatrzymały Pomorze w celu łatwiejszej komunikacji z Prusami Wschodnimi ${ }^{28}$. Podkreślić należy, że stanowisko A. Balfoura potwierdzało głoszoną jeszcze w 1916 r. przez niego wizję Polski małej, słabej, zorganizowanej w ramach Imperium Rosyjskiego.

Niestety to niekorzystne dla Polski stanowisko w sprawie granic z Niemcami, odnosiło się także do granicy wschodniej, przez sprzeciw wobec przyłączenia do Polski ziem Galicji Wschodniej. Fakt ten związany był z notatką referenta do spraw polskich w Political Intelligence Departament of Foreign Office, Lewisa B. Namiera ${ }^{29}$, w której oskarżył on rząd polski o imperialistyczne cele w Galicji, proponując, by rząd brytyjski nakazał rządowi polskiemu

27 Ibidem, s. 81 .

28 H. I. Nelson, Land and Power. British and Allied Policy on Germany's Frontiers 1916-1919, London 1963, s. 7-13.

29 Lewis Bernstein Namier, brytyjski historyk i polityk; główny doradca premiera Dawida Lloyda George'a, na konferencji paryskiej w sprawach polskich; urodził się w Polsce jako Ludwik Bernstein Niemirowski w Woli Okrzewskiej 27.06.1888 r., zmarł 19.08.1960 r. 
przeprowadzenie $\mathrm{w}$ trybie natychmiastowym porozumienia $\mathrm{z}$ Radą Ukraińską. Tak też się stało, rząd brytyjski wystosował oficjalną notę ${ }^{30}$.

Sprawa wschodniej granicy, tak przedstawiana przez Davida Lloyd George’a, czyli Polska bez Lwowa i Zagłębia Borysławskiego, znajdowała uzasadnienie m.in. właśnie $\mathrm{w}$ memoriałach przygotowanych przez Lewisa B. Namiera z 9 grudnia 1918 r., i 7 stycznia 1919 r. Lewis B. Namier w swoich memoriałach proponował, by granice wschodnie Polski, oprzeć geograficznie na dwóch rzekach, mianowicie Bugu i Sanie. Sprzeciwiał się także, by w granicach polskich znalazła się Galicja Wschodnia ${ }^{31}$.

Wracając do kwestii granicy z Niemcami, nawet wyniki raportu, jaki na zlecenie Lloyd George'a został opracowany przez specjalnie w tym celu powołaną i wysłaną na ziemie polskie komisję, również nie zmieniły jego przekonania. Kiedy Komisja rzeczoznawców składała swoje sprawozdanie, dotyczące granic Polski, D. Lloyd George, sprzeciwił się tworzeniu korytarza pomorskiego na tej zasadzie, że „...pewne okręgi zawierały większość niemiecką, przyłączenie ich więc byłoby niebezpieczeństwem dla przyszłego pokoju i dla samej Polski" ${ }^{2}$ Wyliczył, że wytyczenie granic według propozycji komisji J. Cambona oznaczałoby pozostawienie po stronie polskiej 2132000 Niemców i był temu zdecydowanie przeciwny ${ }^{33}$. Był zdecydowanym przeciwnikiem rozdzielenia Prus Wschodnich od Niemiec. Warto podkreślić, że raport sporządzono dwukrotnie i potwierdzał on bezsprzecznie, że ludność zamieszkująca sporne terytoria w większości mówi w języku polskim, kultywuje polską tradycję i chce przynależeć do Polski.

David Lloyd George niezmiennie stał na stanowisku, że Warmia, Mazury, Powiśle, Górny Śląsk oraz Gdańsk nie powinny znaleźć się w granicach państwa polskiego. Szczególnie skomplikowana, obok Gdańska, była kwestia przynależności państwowej Górnego Śląska. Nie wchodził on bowiem w skład I Rzeczypospolitej i od połowy XIV w. pozostawał de iure poza Koroną Polską. Fenomenem było, że wśród ludności wykształciła się i utrzymała świadomość przynależności do narodu polskiego, co generalnie potwierdzał niemiecki spis ludności z 1910 r. Dodatkowo Górny Śląsk był nadzwyczaj ważnym terytorium przemysłowym, którego przynależność do Polski wzmacniałaby potencjał gospodarczy odbudowywanego państwa. Stąd do postulatu polskiej przynależności Górnego Śląska delegacja polska przywiązywała bardzo dużą wagę. W tej kwestii D. Lloyd George zajął stanowisko nieprzejednane. Miał się ponoć

30 Karski J.. Wielkie mocarstwa wobec Polski 1919-1945. Od Wersalu do Jatty, Warszawa 1988, s. 85$-93$.

31 Ibidem, s. 97-101.

32 E.J. Dillon, op. cit., s. 115.

33 K. Lapter, Sprawa Gdańska i dostępu Polski do morza na Konferencji Paryskiej 1919 r., „Przegląd Historyczny" 1954, nr 2-3, s. 469. 
w 1919 r. wyrazić, że oddanie Śląska Polsce równałoby się wręczeniu zegarka małpie $^{34}$. W ten sposób wyrażał swoje negatywne stanowisko wobec polskich zdolności gospodarczych i zarządczych - był to stały element jego poglądów. „Polacy nie mają zrozumienia dla organizacji, nie są zdolni do przewodzenia i rządzenia. Ich premier to pianista, ich prezydent to idealista bez żadnych praktycznych pomysłów" - mówił w 1919 r. na posiedzeniu Rady Dziesięciu ${ }^{35}$. Ostatecznie o przynależności państwowej tych terenów miały rozstrzygnąć plebiscyty, które na mocy postanowień traktatu wersalskiego, miały odbyć się w latach 1920-1921. Szczegółowe przepisy regulujące kwestię plebiscytów na tych terenach, znajdziemy w dziale III, w art. 87-88 Traktatu wersalskiego. Niestety, Polacy przegrywali kolejne plebiscyty na rzecz Niemiec, za przyczyną w dużej mierze kilkuwiekowej podległości administracyjnej tych terenów Niemcom.

Najbardziej negatywne skutki uregulowań traktatu wersalskiego odczuwali Polacy zamieszkujący Górny Śląsk, szykanowani, wręcz terroryzowani przez dominującą władzę administracyjną Niemców. Polacy podjęli na nowo zbrojną walkę i wystąpili przeciwko Niemcom w trzech powstaniach śląskich, przelewając krew za Polskę, za Śląsk, by mógł być włączony w granice Rzeczypospolitej. Okres dwudziestolecia międzywojennego to czas, w którym formowały się więzi na nowym terytorium Polski, wywalczonym dyplomatycznie i zbrojnie. Dokonujący się wówczas proces integracji Górnego Śląska z Polską potwierdzał jego znaczenie dla Rzeczypospolitej.

Traktat wersalski nie uwzględniał wszystkich postulatów polskich wobec niemieckich terytoriów. Jednak bezwarunkowe przyznanie Polsce Pomorza i Wielkopolski, utworzenie Wolnego Miasta Gdańska (gdzie ludność polska nie przekraczała 5\%) było zgodne z polską racją stanu. Wynik plebiscytów też nie musiał być przesądzony - wszak ludność mogła opowiedzieć się za przynależnością do Polski. Szczególnie zgodę na przyznanie Polsce Pomorza uznać należy za zupełną nowość w stanowisku brytyjskim.

Często zapomina się, że sprawa pozostałych granic Polski była również poruszona w traktacie wersalskim. Jeden z ustępów art. 87 stanowił, że „Granice Polski, nieokreślone w niniejszym Traktacie, będą oznaczone później przez Główne Mocarstwa sprzymierzone i stowarzyszone". Tym samym Polska zgodziła się, by decydujący głos w sprawie granic wschodniej, północnej i południowej należał do Ententy. Faktycznie decyzja Ententy zadecydowała jedynie o spornych terytoriach z Czechosłowacją, natomiast granice wschodnie i północne zostały wywalczone orężem. Nie przedstawiając przebiegu wydarzeń,

34 M. Wilamowski, K. Wnęk, L.A. Zyblikiewicz, Leksykon polskich powiedzeń historycznych, Kraków 1999, s. 94.

35 R.M. Watt, Gorzka chwała. Polska i jej los 1918-1939, Warszawa 2007, s. 59. 
odnotować należy stanowisko brytyjskie, które całkowicie nie uwzględniało wschodnich aspiracji Polski. Wspomniana praca A. Nowaka posługuje się $\mathrm{w}$ tym kontekście wątpliwym politycznie pojęciem zdrady. Warto może odnotować, że podjęta na początku lat 20. próba ułożenia się Brytyjczyków z bolszewikami zakończyła się dla tych pierwszych całkowitym blamażem. Do tego błędu D. Lloyd George nigdy się nie przyznał.

Podkreślenia w tym miejscu wymaga fakt, iż poglądy Davida Lloyd George'a na sprawę polską zmieniały się w zależności od sytuacji geopolitycznej w Europie. Zwłaszcza wydarzenia, które dokonywały się na ziemiach rosyjskich: upadek carskiej Rosji, rozlewający i zagrażający całej Europie bolszewizm, miały ogromny wpływ na kierunek jego polityki co do granicy polsko-rosyjskiej. Zapewne dużą rolę odegrało zafascynowanie osobą I. Paderewskiego, którego podziwiał i z którym wiele razy jeszcze przed konferencją paryską się spotykał. Gdyby pominąć całkowitą niewiedzę Davida Lloyd George’a, zarówno historyczną, jak i geograficzną, która zupełnie go nie krępowała, można by powiedzieć, że - jako Walijczyk, czyli przedstawiciel narodu uciśnionego przez Anglików - sympatyzował z Polską.

Dla przykładu, D. Lloyd George stanowczo przeciwstawił się w marcu 1919 r. apelom generała Jana Smutsa - południowoafrykańskiego członka gabinetu imperialnego. Generał J. Smuts, który Polaków porównał do kafirów, to znaczy: niewolników, apelował z całą stanowczością, by nie tworzyć „zamku na piasku", jakim z pewnością okaże się Polska ${ }^{36}$. David Lloyd George jednak stanął w tym miejscu w obronie Polaków, popierając jednoznacznie ich starania o niepodległość. Niestety, kolejne wydarzenia polityczne sprawiły, że szybko swoje poglądy na sprawę polską zweryfikował i opowiedział się za nieosłabianiem Niemiec, nie zważając, że cenę za jego politykę zapłacą Polacy. Jednak nawet wtedy, stosując zasadę samostanowienia narodów, uzasadniał oddanie Polsce Pomorza. Oryginalne było jego tłumaczenie w sprawie przyznania Polsce niemieckojęzycznego Międzychodu (Birnbaum), otoczonego przez polski powiat: w Liverpoolu mieszkają Irlandczycy, ale nikt nie żąda przyłączenia tego miasta do Irlandii ${ }^{37}$. W ten sposób Międzychód stał się najbardziej wysuniętym na zachód miastem II RP.

Imperialistyczne poglądy D. Lloyd George’a, które zawsze były dla niego wyznacznikiem $\mathrm{w}$ prowadzonej polityce, nie pozwalały mu na zrozumienie dla postulatów polskich. Polakom nie wolno było być „imperialistami”. W swych słowach potępiał Polaków, uznając, że ich żądania do odbudowy Polski $\mathrm{w}$ przedrozbiorowych granicach są wyrazem niemoralnego imperializmu małego narodu ${ }^{38}$. Tym samym poparcia swego udzielił Rosji i Niemcom, uza-

36 A. Nowak, Pierwsza zdrada zachodu 1920. Zapomniany Appeasement, Kraków 2016, s. 319.

37 D. Lloyd George, op. cit., s. 271.

38 Ibidem, s. 321. 
sadniając, że sporne tereny przez cały okres zaborów przynależały do ich organizmów państwowych.

Powyższe fakty ukazują wielce skomplikowaną materię polityki Davida Lloyd George’a i zmienność jego zapatrywań na sprawę polską oraz brak stałych założeń polityki na tym polu. Jego nieprzychylność do sprawy polskiej na konferencji pokojowej w Paryżu, wzmacnianie pozycji Rosji, a nawet przegranych Niemiec, znalazły swój wyraz w Traktacie Wersalskim. Jednakże pokój, ustanowiony na tej konferencji, pozostał niedokończony, a o tym że faktycznie zapanował w Europie, na wschód od niemieckiej granicy, zadecydowali polscy żołnierze walczący pod Warszawą i nad Niemnem, od sierpnia do września 1920 r. $^{39}$, zatrzymując marsz bolszewików na Europę.

Nie jest celem niniejszego opracowania wykazanie niechęci czy sympatii premiera Wielkiej Brytanii Davida Lloyd George’a do Polski i Polaków. Jednakże, dokonując analizy jego sylwetki oraz podejmowanych przez niego decyzji, wyłania się jednoznaczny obraz polityka niechętnego sprawie Polski. Rozgrywał kosztem Polski interesy własnego państwa, patrząc na kwestie geopolityczne powojennej Europy przez pryzmat gospodarczych i politycznych korzyści dla swojego kraju. Zapytany po konferencji jak ocenia swój wkład w ustalenie granic jednego z nowo powstałych państw w Europie Środkowej, odpowiedział: „Myślę, że zrobiłem to, czego się można było spodziewać, siedząc tak, jak siedziałem, między Jezusem Chrystusem (Wilsonem) a Napoleonem Bonaparte (Clemenceau) ${ }^{40}$. Próbował wszelkimi dostępnymi środkami niedopuścić do wzmocnienia w Europie pozycji Francji, odwiecznego rywala Wielkiej Brytanii. Był tak przekonany o słuszności zajętego w 1919 r. stanowiska, że po agresji hitlerowskiej na Polskę komentował, że zasłużyła ona na swój $\operatorname{los}^{41}$. Wyrażał tym samym błędne przekonanie, jakoby przyczyną ataku Niemiec na Polskę były postanowienia Traktatu Wersalskiego, a nie hitlerowskie dążenie do panowania nad światem.

David Lloyd George bezsprzecznie zajmował pierwsze miejsce wśród czołowych przywódców powojennego świata. Był politykiem umiejętnie rozgrywającym na arenie międzynarodowej, mającym największy wpływ na mapę powojennej Europy. Realizował politykę brytyjskiego imperializmu na świecie, odchodzącego do przeszłości w szybkim tempie. Jego postawa zmusza do refleksji: miejsce Polski wśród niepodległych państw Europy nie było oczywiste, przez długi czas traktowano Polskę bardziej jako problem niż jako element stabilizujący ${ }^{42}$. Jeszcze mniej oczywiste były sprawiedliwe granice państwa

39 A. Nowak, op. cit., s. 110.

40 E. J. Dillon, op. cit., s. 110

41 N. Davies, Boże igrzysko. Historia Polski, Kraków 2007, s. 861.

42 Sam D. Lloyd George nazywał Polaków „Irlandczykami kontynentu”. J. Złotkiewicz-Kłębukowska, op. cit., s. 47. 
polskiego. Warto o tym pamiętać dzisiaj, kiedy zupełnie poważnie traktowane są opinie rosyjskich polityków uzasadniających pakt Ribbentrop-Mołotow.

\section{Bibliografia}

Batowski H., Między dwoma wojnami 1919-1939. Zarys historii dyplomatycznej, Kraków 2001.

Cienciała A.M., Polityka brytyjska wobec Odrodzenia Polski 1914-1918, „Zeszyty Historyczne" 1969, nr 16.

Czubiński A., Historia Powszechna XX wieku, Poznań 2003.

Davies N., Boże igrzysko. Historia Polski, Kraków 2007.

Davies N., Lloyd George i Polska 1919-1920, Gdańsk 2000.

Dillon E. J., Konferencja Pokojowa w Paryżu 1919, Warszawa 1921.

Drozdowski M. M., Ignacy Jan Paderewski, Warszawa 1986.

Fiedorczyk P., Lityński A., Stawarska-Rippel A., Wojny XX wieku i ich skutki dla ustrojów państwowych i prawa, „Czasopismo Prawno-Historyczne” 2019, t. LXXI, z. 1.

Karaszewski P., Kryzys autorytetu Foreign Office w latach 1914-1922, „Dzieje Najnowsze” 1977, z. 2.

Karski J., Wielkie Mocarstwa wobec Polski 1919-1945. Od Wersalu do Jałty, Warszawa 1988.

Kuk L., Między wielkościa a małościa. Polska wobec koncertowej kakofonii mocarstw na przełomie swych dziejów (1914-1945), „Kwartalnik Historyczny” 2017, z. 1.

Lapter K., Sprawa Gdańska i dostępu Polski do morza na Konferencji Paryskiej 1919 r., „Przegląd Historyczny” 1954, nr 2-3.

Lloyd George D., Prawda o traktacie wersalskim, t. I-II, Warszawa 1938.

Nelson I. H., Land and Power, British and Allied Policy on Germany's Frontiers 19161919, London 1963.

Nowak A., Pierwsza zdrada Zachodu. Zapomniany Appeasement, Kraków 2016.

Płygawko D., Sienkiewicz w Szwajcarii, Poznań 1986.

Prokop K., Dyktatura brytyjskiego gabinetu w czasie I wojny światowej, [w:] Prawo, parlament i egzekutywa we wspótczesnych systemach rząów: księga poświęcona pamięci Profesora Jerzego Stembrowicza, red. S. Bożyk, Białystok 2009.

Samsel K., Publicystyka niepodległościowa Josepha Conrada i jej postromantyczne uwikłania, „Perspektywy Kultury” 2019, t. 24, nr 1.

Sierpowski S., Studia do historii powszechnej okresu międzywojennego, t. 1, Poznań 1989. Sprawy polskie na konferencji pokojowej w Paryżu w 1919 roku. Dokumenty i materiaty, red. R. Bierzanek, J. Kukułka, t. 1, Warszawa 1965. 
Sprawy polskie na konferencji pokojowej w Paryżu w 1919 roku. Dokumenty i materiały, red. R. Bierzanek, J. Kukułka, t. II, Warszawa 1967.

Sprawy polskie na konferencji pokojowej w Paryżu w 1919 roku. Dokumenty i materiały, red. R. Bierzanek, J. Kukułka, t. III, Warszawa 1968.

Sukiennicki W., Balfour a Polska, „Zeszyty Historyczne” 1970, nr 17.

Traktat między głównemi Mocarstwami sprzymierzonemi i stowarzyszonemi a Polską, podpisany w Wersalu 28 czerwca 1919 r. (Dz.U. $1920 \mathrm{nr}$ 110, poz. 728).

Traktat pokoju między mocarstwami sprzymierzonemi i skojarzonemi i Niemcami, podpisany w Wersalu 28 czerwca 1919 r. (Dz.U. $1920 \mathrm{nr}$ 35, poz. 200).

Ustawa z dnia 31 lipca 1919 r. o ratyfikacji traktatu pokoju (Dz.U. $1920 \mathrm{nr}$ 35, poz. 199). Watt M.R., Gorzka chwała. Polska i jej los 1918-1939, Warszawa 2007.

Wilamowski M., Wnęk K., Zyblikiewicz A. L., Leksykon polskich powiedzeń historycznych, Kraków 1999.

Złotkiewicz-Kłębukowska J., Od Balfoura do Curzona. Polityka Wielkiej Brytanii wobec odradzajacej się Polski, „Annales Universitatis Mariae Curie-Skłodowska. Sectio F - Historia" 2009, t. LXIV.

\section{STRESZCZENIE}

\section{David Lloyd George a sprawa polska na konferencji wersalskiej}

David Lloyd George a sprawa polska na konferencji wersalskiej, artykuł, który zdecydowałem się tak zatytułować, mam nadzieję skompensował wiedzę w tym temacie. Starałem się w swojej pracy wykorzystać jak najwięcej obecnych na rynku publikacji, które dotykają problemu. Nie ulega wątpliwości, że po wnikliwej analizie artykułu ujawnia się postawa brytyjskiego premiera Davida Lloyd George’a, jako polityka wręcz niechętnego sprawie polskiej. Na pozór sprzyjającego Polakom i popierającego dążenia narodowowyzwoleńcze, ale w efekcie w takiej formie, jaką Wielka Brytania zaproponowała. Nie do zaakceptowania przez Davida Lloyd George’a okazały się żądania Polaków wysuwane na konferencji wersalskiej, gdyż ten, będąc bezsprzecznie sprawnym graczem na arenie międzynarodowej sprawę polską rozpatrywał pod kątem korzyści bądź zagrożeń, jakie mogły one stanowić dla Brytyjczyków. Generalnie, wiele z polskich postulatów nie zgadzało się z nakreślonym przez Davida Lloyd George'a stanowiskiem brytyjskim. Istotnie należy przypomnieć, że Wielka Brytania przystępując do I wojny światowej nie nakreśliła jednoznacznie swoich celów wojennych w sprawie polskiej, jednakże już wtedy sygnalizowała uzależnienie podjęcia polskiej sprawy od sukcesów armii rosyjskiej. Przez cały czas trwania konferencji wersalskiej dyskusje dotyczące sprawy polskiej toczyły się przez pryzmat interesów Niemiec i Rosji. Przy jednoczesnym osłabianiu roli Francji, w czym jako żywo był zainteresowany rząd brytyjski. Tenże zlecał swojemu Foreign Office przygotowanie warunków do negocjacji dla przyszłego pokojowego ładu w Europie i tak powstawały kolejne memoriały, w których pojawiał się problem granic polskich. Życzeniem bry- 
tyjskiej dyplomacji początkowo było, by Polska pozostawała wewnątrz granic Rosji z niewielką autonomią. Dopiero, gdy do gry włączył się prezydent USA Thomas W. Wilson ogłaszając w dniu 22 stycznia 1917 r. postulat utworzenia wolnej Polski, Brytyjczycy zmienili swoje dotychczasowe stanowisko, ale wciąż odmawiali Polakom wolnego dostępu do morza, Gdańska i województwa poznańskiego. Kwestie te jednak uległy kolejnym zmianom, a kwestia wolnej Polski znalazła się w oficjalnym stanowisku jako cel wojenny Wielkiej Brytanii. Bezpośrednio po tym, jak przez Rosję przetoczyła się rewolucja i upadł carat. Poza toczącymi się rozmowami bezpośredni wpływ na ukształtowanie się granic niepodległej Polski miały raporty komisji J. Cambona, powołanej do przeprowadzenia działań w terenie, które przedstawiały propozycje przeprowadzenia granic i propozycje przeprowadzenia w przyszłości plebiscytów. Wnioski wynikające z raportów J. Cambona oczywiście napotkały na silny opór ze strony Davida Lloyd George’a, który w tym samym czasie otrzymywał kolejne memoriały, tym razem dotyczące granicy wschodniej wolnej Polski, skreślone ręką Lewisa B. Namiera. Gorącego przeciwnika, by Galicja Wschodnia znalazła się w granicach państwa polskiego, oskarżającego polski rząd o imperialistyczne cele w Galicji. Ostatecznie, Traktat Wersalski nie utrwalił pokoju w Europie, która na długo jeszcze była areną powstań i wojen, dotyczących w ogromnej mierze Polaków, przy ich aktywnym udziale.

\section{SUMMARY}

\section{David Lloyd George the Polish matter during the Versailles Conference}

David Lloyd George and the Polish matter at the Versailles Conference - the article which I decided to title as such, I hope, has covered the knowledge on the subject. In my work, I have tried to make use of as many of the works which are present on the publication market as possible and are relevant to the subject. There is no doubt that after a thorough analysis of the literature, the attitude of the British Prime Minister, David Lloyd George, as a politician who is reluctant to take up the Polish matter, is revealed. Seemingly he is in favour of Poles and supports their national liberation efforts, in a form proposed by the United Kingdom in effect. Demands made by Poles at the Versailles Conference turned out to be unacceptable to David Lloyd George, because he, being an unquestionably efficient player on the international stage, considered the Polish matter from the point of view of the benefits or threats it could pose to the British people. In general, many of the Polish demands did not agree with the British position outlined by David Lloyd George. It should indeed be remembered that the United Kingdom, when it joined the First World War, did not clearly set out its war objectives on the Polish matter, but it was already signalling that its undertaking of the Polish matter was dependent on the success of the Russian army. Throughout the entire length of the Versailles Conference, discussions on the Polish matter were held through the lens of German and Russian interests. Simultaneously, the role of France was weakening, in which the British Government was keenly interested. The 
British Government also commissioned its Foreign Office to prepare the terms for negotiations for a future peaceful order in Europe, and so successive memoranda were created in which the problem of the Polish borders arose. The wish of British diplomacy was initially that Poland should remain within the borders of Russia with little autonomy. It was only when US President Thomas Woodrow Wilson joined the game, and when he announced on 22nd January 1917 demands for the creation of a free Poland, that the British changed their previous position, but still denied Poles free access to the sea, Gdańsk and the Poznań region. However, these issues have changed again and again, and the question of a free Poland has been included in the official position as a war objective of the United Kingdom. This occurred immediately after the revolution swept through Russia and Tsarism collapsed. In addition to the ongoing discussions, the reports of the Jules Cambon Commission, a committee set up to carry out activities on the ground, which presented proposals to establish borders and proposals for future plebiscites, had a direct impact on the formation of the borders of an independent Poland. The conclusions from Mr Cambon's reports obviously met with strong resistance from David Lloyd George, who at the same time received further memoranda, this time concerning the eastern border of free Poland, struck through by Lewis Bernstein Namier, a fervent opponent for Eastern Galicia to find itself within the borders of the Polish state, accusing the Polish Government of imperialist intentions in Galicia. After all, the Treaty of Versailles did not consolidate peace in Europe, which was for a long time to come an arena of uprisings and wars, which affected Poles to a great extent, with their active participation. 